DOI https://doi.org/10.18551/rjoas.2018-10.26

\title{
PEDIGREE SELECTION TO OBTAINED RICE VARIETIES ADAPTED TO LOW PHOSPHORUS CONDITIONS
}

\author{
Hermanasari Rini*, Suwarno \\ Muara Experimental Farm, Indonesia Center for Rice Research, Bogor, Indonesia
}

Ardie Sintho Wahyuning, Ghulamahdi Munif, Aswidinnoor Hajrial

Department of Agronomy, Faculty of Agriculture, Bogor Agriculture University, Indonesia

*E-mail: hermanasari@yahoo.co.id

\begin{abstract}
To get adaptive varieties in $\mathrm{P}$ sub-optimum conditions needs selection method effective. This research aimed to generate rice lines adaptive to $P$ sub-optimum condition through rice lines selection on the availability of the difference $P$ condition. The research was carried out during four seasons from April 2012 to December 2014 in Muara Experimental Farm, Bogor and farmers' land in the Leuwiliang village. The material used breeding populations from IR6008023/Bernas Prima and Gampai/Progol. Selections conducted for an F3 generation without $P(P-)$ and generation $F 4$ to $F 5$ in two selection environments adequate of $P(P+)$ and without $P(P-)$, by used pedigree method selection. The individual selection in F5 to select 40 lines from each population and soil condition, so that resulting totaled 160 breeding lines. The lines evaluated in $\mathrm{P}+$ and $\mathrm{P}$ - environment, following an augmented design, with five blocks and five checks. The data showed that the average of grain yield on $\mathrm{P}+$ was not significantly different from the environment of selection but between the population is significantly different, on the contrary of without $\mathrm{P}$ was not significantly different both of environment selection nor population. The average yields of the lines which selection on Psignificant higher from $\mathrm{P}+$. Most of the selected lines for $\mathrm{P}$ - are not different from the selected lines for $\mathrm{P}+$. The pedigree selection method applied to the results of early generation rice crosses up to $\mathrm{F} 4$ followed by line selection, can produce adaptive and high yielding lines in the $\mathrm{P}+$ and $\mathrm{P}$-.
\end{abstract}

\section{KEY WORDS}

Pedigree selection method, rice lines, selection environment, production environment, optimum, sub-optimum, phosphorus

Rice is a staple food for almost $95 \%$ of Indonesia's population. The rate of population growth in Indonesia is high, causing a high demand for national food production, especially rice. The availability of agricultural land is in contrast to efforts to increase rice production. The availability of land both in quantity and quality, such as the fertility of agricultural land decreased due to the use of improper production technology and land conversion. According to Mulyani et al. (2011), the most agricultural land fertile used for various sectors, both agriculture and non-agricultural sectors (industry, infrastructure, and settlements), even irrigation land decreased due to conversion. Therefore, the development of agriculture in the future is to optimize the use of suboptimum lands such as rainfed fields, dry land, and swampland or tidal swamps.

Problems encountered on the suboptimum land include the low nutrient content of Phosphorus (P) (Suharta 2010). Phosphorus is an essential nutrient for plant growth (Vance et al 2003; Balemi and Negisho 2012). Although phosphorus for plants important the availability of phosphorus in the soil is very small because $P$ tends to be bound by other compounds such as Al and Fe (Richardson et al 2009). The availability of nutrients in tropical soils is low, limiting agricultural productivity (Parentoni et al., 2012). The low availability of $P$ especially in developing countries, where access to $P$ fertilization is limited, poses a challenge in the development of crops, especially rice, varieties adaptive to efficiency $P$ are 
needed to utilize the $P$ deficiency farm. Efficient plants $P$ is needed to minimize the use of $P$ inputs and to reduce the loss of $P$ from the environment (Richardson et al., 2009). Besides that, the varieties which adaptive to low $P$ condition used in the land with low input $P$.

Indonesia is one of the countries which having phosphorus deficiency problem. This nutrient deficiency can occur in dryland or irrigated fields. Dryland in Indonesia dominated by Ultisol the main constraint the excess of $\mathrm{Al}$ element that can bind $\mathrm{P}$, whereas, in irrigation fields that are inundated by water, the dominant Fe element binds P. So many lands with that conditions in Sumatera, Kalimantan, Papua and parts of Java. Therefore, need rice variety are tolerant of $P$ deficiency (Prasetyo and Suriadikarta 2006).

Rice breeding for acid soils has been conducted in Indonesia, but emphasized on tolerance to $\mathrm{Al}$ and Fe toxicity and not on tolerance to P deficiency (Lubis et al. 2008; Hermanasari et al. 2011; Hairmansis et al. 2013). The breeding process is carried out in the optimum environment resulting in improved yielding varieties only adaptive to fertile land. The potential yields of these improved varieties will decrease when planted on suboptimum land (Wang et al. 2010; Fess et al. 2011; Wissuwa et al. 2009). Therefore, it is necessary to adaptive paddy varieties at suboptimum $P$ condition.

Developing adaptive varieties on the condition low $\mathrm{P}$ land has been done both conventionally and molecularly. The selection process using molecular markers will be more effective and efficient (Acquaah 2007). Wissuwa et al., (1998) evaluated the presence of genes that regulate the absorption of $\mathrm{P}$ on the condition land less $\mathrm{P}$. The gene is called Pup 1 (Phosphorus uptake 1), in rice plants located on chromosome 12. Chin et al., (2011) reported that Pup 1 significantly increased grain yields on condition low input P. GamuYao et al., (2012) gets a gene for increasing $P$ uptake, called Phosphorus-starvation tolerance 1 (PSTOL1). Pariska et al., (2014) developed several molecular markers to transfer PSTOL1 genes from the Kasalath variety to African Mega varieties. Pup 1 segment introgression into rice varieties from Indonesia (Situ Bagendit and Batur) has been done and successfully obtained some positive lines containing Pup1 segment (Prasetiyono 2010).

One of the efforts to obtain adaptive crops on condition low $P$ is conventionally through the breeding program to get varieties that tolerance to $P$ deficiency. The concept of plant breeding to assemble varieties that are tolerant of abiotic environments is to create new genes recombination by utilizing genetic diversity derived from various genetic sources or introduction of germplasm through the merging of two elders that have properties according to the desired characteristics. The success of the breeding program is the selection method. The method of selection commonly used by self-pollinated crops such as rice is a pedigree method. This method effective for qualitative characters which are control by a monogenic gene, so easily identifiable in the early generations and the selection continued until it reaches genetic purity. This study aims to produce adaptive rice lines on suboptimum land through the selection of rice lines in condition low $P$ and adequate $P$. Adaptive lines in the suboptimum environment can be utilized by farmers to reduce the use of $P$ fertilizer.

\section{MATERIALS AND METHODS OF RESEARCH}

The research conducted during four planting seasons from April 2012 until December 2014 in the experimental farm Muara Bogor and Leuwiliang Village (Bogor Regency). Analysis of soil samples taken from the experiment sites prior to the experiments indicated that the soil at Muara had $\mathrm{pH}$ of $5.3-5.6$, and available $\mathrm{P}$ of 3.8 (very low) -7.1 (low), whereas at Leuwiliang had $\mathrm{pH}$ of $4.6-4.9$ and available $\mathrm{P}$ on 1.8 (very low) -4.3 (low).

Two F2 populations of crosses IR6008023/Bernas Prima (Pop1) and Gampai/Progol (Pop2) were selected from breeding materials available in Indonesian Center for Rice Research (ICRR). IR6008023 is a breeding line tolerant to Al toxicity developed by International Rice Research Institute (IRRI) Bernas Prima is a hybrid rice variety with high yielding capacity, Progol is a traditional variety with big panicle, and Gampai is the traditional variety with high tillering and resistant to blast disease (Lubis et al. 2007; Hairmansis 2016). The F2 populations were cultivated on size $2 \times 8$ m plots with $20 \times 20 \mathrm{~cm}$ plant spacing in the soil with $\mathrm{P}(\mathrm{P}+), \mathrm{N}$ and $\mathrm{K}$ fertilizer application of $36 \mathrm{~kg} \mathrm{ha}^{-1}$ of $\mathrm{P}_{2} \mathrm{O}_{5}, 135 \mathrm{~kg} \mathrm{ha}^{-1}$ of Nitrogen 
and $60 \mathrm{~kg} \mathrm{ha}^{-1}$ of $\mathrm{K}_{2} \mathrm{O}$. Fertilizer $\mathrm{P}$ and $\mathrm{K}$ applied at transplanting time, $\mathrm{N}$ fertilizer respectively $45 \mathrm{~kg} \mathrm{ha}^{-1}$ applied at 0,4 , and 7 weeks after transplanting, Harvest conducted by collecting 3-4 seeds from each plant except for those with very tall or very late maturing.

The F3 populations cultivated with the same method as F2 but in without $\mathrm{P}$ condition (P-) with only $\mathrm{N}$ and $\mathrm{K}$ fertilizer application of $45 \mathrm{~kg} \mathrm{ha}^{-1} \mathrm{~N}$ and $60 \mathrm{~kg} \mathrm{ha}^{-1} \mathrm{~K}_{2} \mathrm{O}$. Planting population of generation F3 done in dry season at experimental farm Muara Bogor on April until August 2012. The variables measured plant height, panicle weight, and panicle length. Harvest is done by taking a panicle from each plant.

Planting population of generation F4 conduct in experimental farm Muara, in rainy season 2012/2013. A total of 150 panicles planted in a row per panicle along $4 \mathrm{~m}$ with a distance between rows of $20 \mathrm{~cm}$ and a distance in rows of $20 \mathrm{~cm}$. Each is planted in two different environments optimum of $\mathrm{P}(\mathrm{P}+)$ and without $\mathrm{P}(\mathrm{P}-)$. Individual selection based on criteria: plant height, number of productive tillers, panicle length, panicle weight, panicle weight per hill, grain filled and weight of 1000 grains. Research materials were selected based on panicle weight per hill for the next generation.

The F5 generation population grew in the dry season of 2013 at two locations, namely Experimental farm Muara for the optimum of $\mathrm{P}(\mathrm{P}+)$ and Leuwiliang Village for $\mathrm{P}$ suboptimum $(\mathrm{P}-)$. Planting is the same as the F4 generation population. The selection conducted based on panicle weight per hill, lines selected in this experiment as a material for the next season.

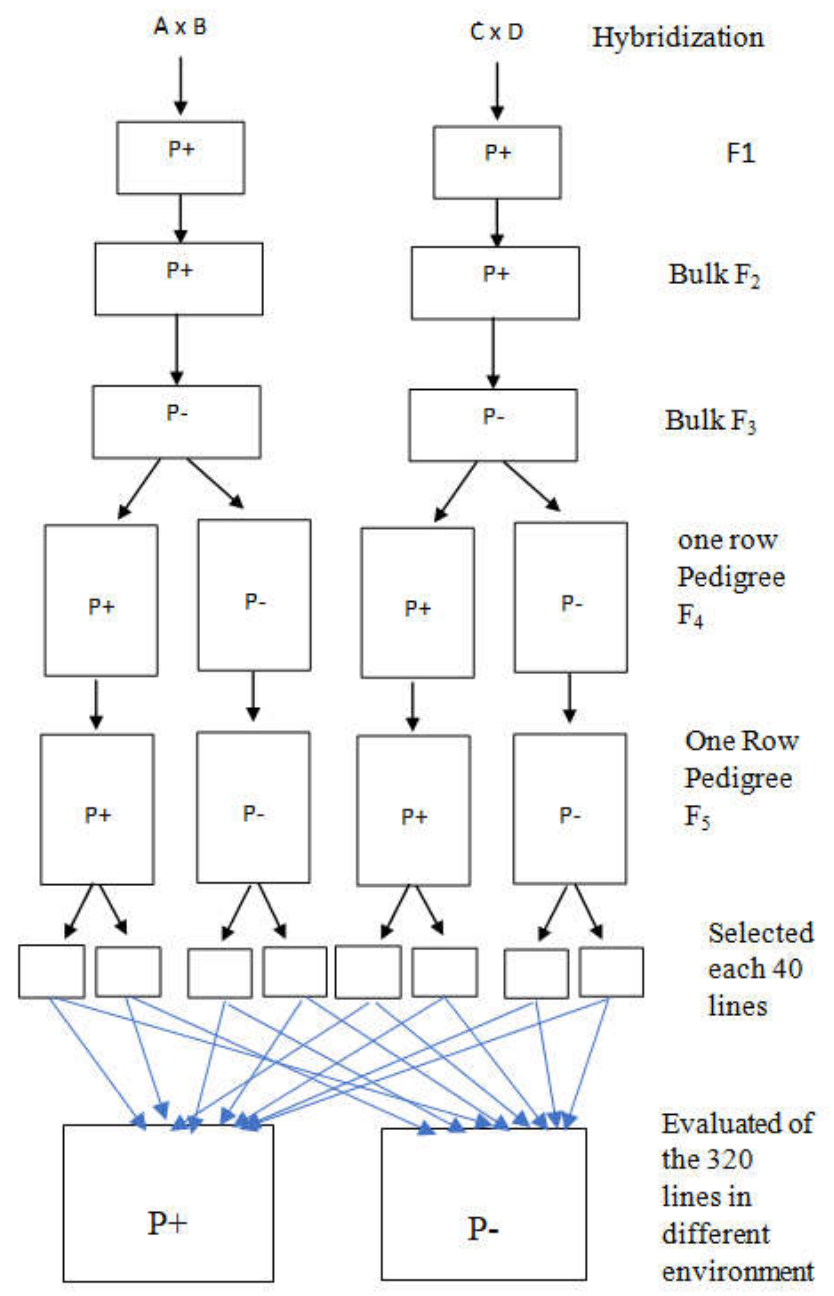

Figure 1 - The scheme of activity for the formation of $\mathrm{F} 6$ rice line from the crossing uses the pedigree selection method (A: IR6008023; B: Bernas Prima; C: Gampai; D: Progol)

The individual selection based on the character of yield to get 40 lines from each population, and soil $\mathrm{P}$ condition resulting totaled 160 lines of F6. The breeding schemes of 
the lines presented in Fig 1. Selected breeding lines evaluated on $\mathrm{P}+$ and $\mathrm{P}$ - following an Augmented design with 5 blocks, $1 \times 5 \mathrm{~m}$ plots and 5 check varieties including Ciherang, Gampai, Inpari 13, Inpari 30, and IR64 (Peterson,1994; Lestari et al 2016). Transplanting method followed for the cultivation with 20-day seedling age, $20 \times 20 \mathrm{~cm}$ plant spacing, and intensive management of weed, pests, and diseases. The observation on maturity for plant height, number of productive tillers, panicle length, number of filled grain, 1000 grain weight. a weight of panicle and yield.

Data analyzed following augmented design using SAS 9.1, Microsoft Excel 2007 and Minitab 13. The mean for the treatments was determined using the t-test at $0.05 \%$ probability level.

\section{RESULTS AND DISCUSSION}

Performance population generation F3, F4, and F5. The average of the height plant, panicle weights, and the panicle length of the lines generation of F3, F4, and F5 of two populations which is select on the environment optimum $P$ and without $P$ are respectively presented in Figures 2, 3, and 4. The averages of the plant height of the generation F4 higher from F3 and F5 generation (Fig. 2). The average of panicle weight and panicle length of the lines generation of F3, F4, and F5 show that Pop 1 populations are always higher than Pop 2 both in the selection environment P- or P+ (Fig. 3 and 4). Differences between generations of selection are thought to be due to differences in the plant season and not by genetic factors.

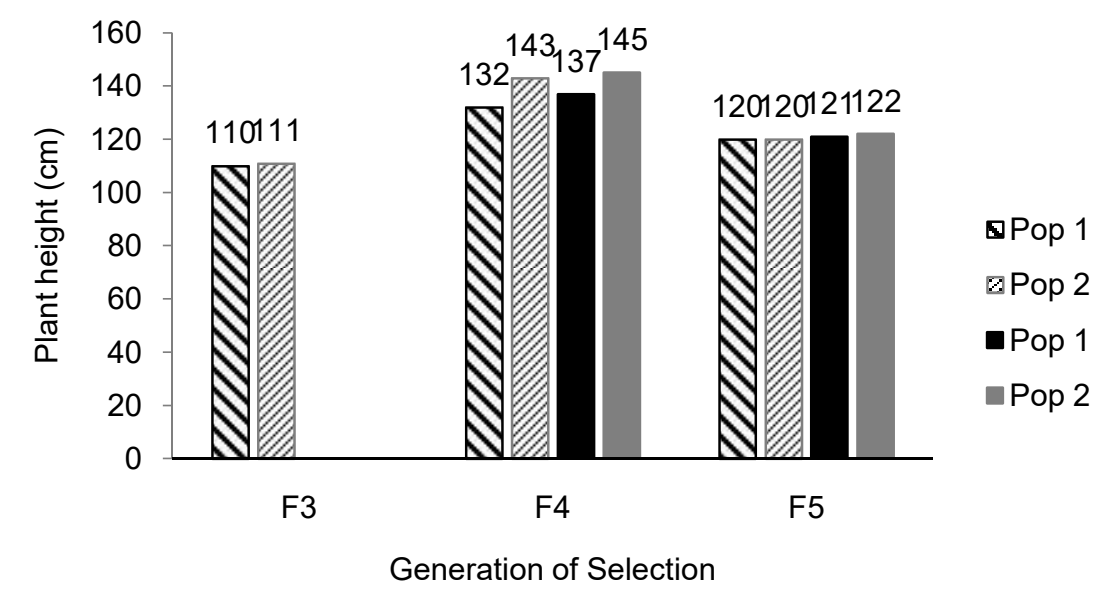

Figure 2 - Average plant height of two generations of F4 and F5 populations in environments without $\mathrm{P}(\mathrm{P}-)$ and adequate of $\mathrm{P}(\mathrm{P}+)$

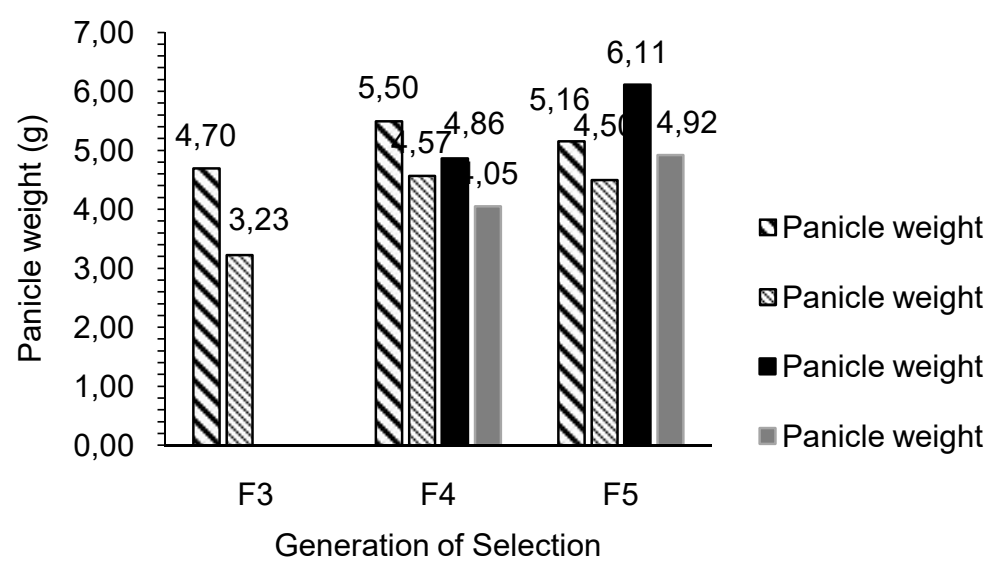

Figure 3 - Average of panicle weight of two generations of F4 and F5 populations in environments without $P(P-)$ and adequate $P(P+)$ 


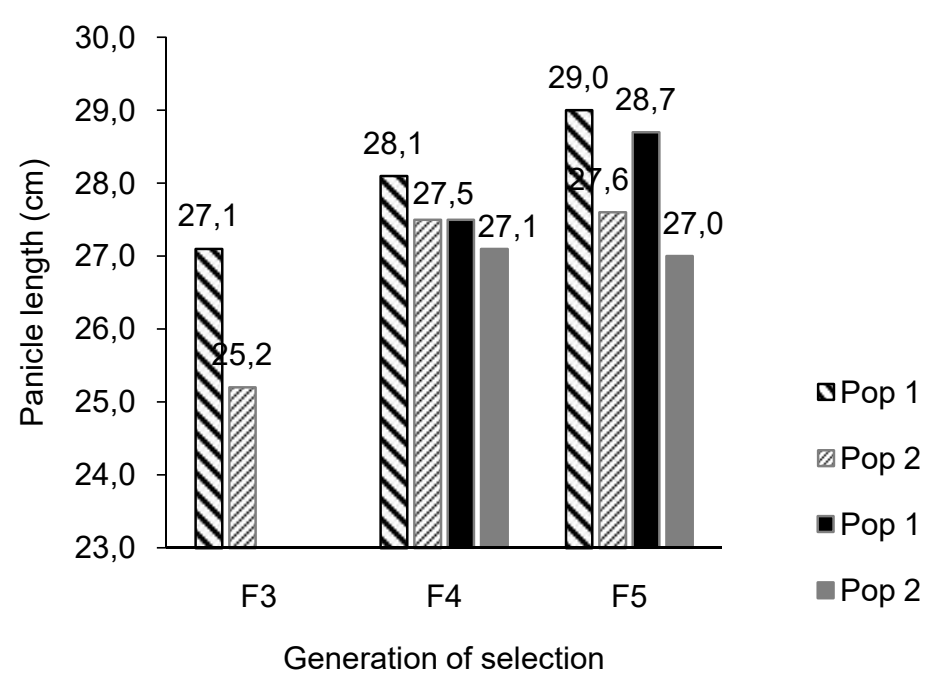

Figure 4 - Average of a panicle length of two generations of F4 and F5 populations in environments without $P(P-)$ and adequate of $P(P+)$

Analysis of variance for yield and yield component in the F6 generation. Analysis of variance for yield and yield component presented in Table 1. The results showed that the block had a significant effect on yield, panicle weight, number of filled grain, 1000 grain weight, panicle length, plant height and days to $50 \%$ flowering. The lines observed on each experimental block are different but the same as the varieties of comparison. Then need the adjusted with the block, because using augmented design (Table 1).

Table 1 - Analysis of variance for different traits in rice lines for the F6 generation, evaluated in different availability phosphorus

\begin{tabular}{llllllllll}
\hline Source of variance & df & 1 & 2 & 3 & 4 & 5 & 6 & 7 & 8 \\
\hline Block & 4 & $4.5^{* *}$ & $11.2^{*}$ & $4678.6^{*}$ & $7.8^{*}$ & $27.5^{* *}$ & $37.6 \mathrm{~ns}$ & $333.7^{*}$ & $51.5^{*}$ \\
Phosphorus & 1 & $14.4^{* *}$ & $4.3 \mathrm{~ns}$ & $10771.5^{*}$ & $6.8 \mathrm{~ns}$ & $30.5^{*}$ & $22.2 \mathrm{~ns}$ & $251.1 \mathrm{~ns}$ & $824,4^{* *}$ \\
Block*Phosphorus & 4 & $1.6^{*}$ & $2.3 \mathrm{~ns}$ & $794.1 \mathrm{~ns}$ & $6.7^{*}$ & $6.8 \mathrm{~ns}$ & $39.8 \mathrm{~ns}$ & $183.8 \mathrm{~ns}$ & $64.6^{*}$ \\
Line_vs_control & 1 & $5.0^{*}$ & $102.2^{* *}$ & $29775.7^{* *}$ & $139.4^{* *}$ & $595.4^{* *}$ & $744.4^{* *}$ & $22410.8^{* *}$ & $103.4^{*}$ \\
Control & 4 & $1.4^{*}$ & $3.3 \mathrm{~ns}$ & $1517.5^{*}$ & $20.3^{* *}$ & $16.8^{*}$ & $33.5 \mathrm{~ns}$ & $286.2^{*}$ & $81.2^{*}$ \\
Line & 78 & $2.6^{* *}$ & $1.6 \mathrm{~ns}$ & $2566.2^{* *}$ & $9.0^{* *}$ & $16.4^{* *}$ & $15.0 \mathrm{~ns}$ & $188.1^{*}$ & $42.5^{*}$ \\
Phosphorus*Line_vs & 1 & $6.9^{*}$ & $1.2 \mathrm{~ns}$ & $29.8 \mathrm{~ns}$ & $0.3 \mathrm{~ns}$ & $14.1^{*}$ & $5.3 \mathrm{~ns}$ & $3.3 \mathrm{~ns}$ & $77.5^{*}$ \\
chtrol & & & & & & & & & \\
Phosphorus*${ }^{*}$ control & 4 & $1.2 \mathrm{~ns}$ & $2.2 \mathrm{~ns}$ & $387.5 \mathrm{~ns}$ & $1.3 \mathrm{~ns}$ & $6.2 \mathrm{~ns}$ & $34.7 \mathrm{~ns}$ & $170.5 \mathrm{~ns}$ & $46.0^{*}$ \\
Phosphorus & 78 & $2.6^{* *}$ & $1.0 \mathrm{~ns}$ & $1135.1^{*}$ & $5.7^{*}$ & $17.5^{* *}$ & $17.6 \mathrm{~ns}$ & $242.1^{*}$ & $62.0^{* *}$ \\
\hline${ }^{1} \mathrm{CV}(\%)$ & & 16.9 & 36.3 & 21.1 & 5.4 & 6.5 & 41.3 & 9.3 & 3.8 \\
\hline
\end{tabular}

${ }^{*}=$ significant, ${ }^{* *}=$ significantly, $n s=$ no significant at level $5 \%$.

${ }^{1} \mathrm{CV}(\%)=$ Coefficient Variance.

1=Yield ( ha $^{-1}$ ), 2=Panicle weight (g), 3= Number of filled grain, 4=1000 grain weight $(\mathrm{g})$, 5= Panicle Length (cm), $6=$ Number of productive tiller, $7=$ Plant height $(\mathrm{cm}), 8=$ days to $50 \%$ flowering.

Interaction of phosphorus with control had a significant effect for character days to $50 \%$ flowering, but no significant effect on yield and the other characters. That means there is no difference in response to phosphorus between varieties of control. The interactions of phosphorus and lines have a very significant effect on all character, excepted panicle weight and the number of productive tillers. That means there is a difference in response to phosphorus or line. The difference of response seen for all observed (Table 1).

The performance of the population F6 generation. The overall data from the yield variable showed that condition of environment adequate $P(P+)$ more high $\left(4.63 \mathrm{t} \mathrm{ha}^{-1}\right)$ than without $\mathrm{P}\left(\mathrm{P}_{-}\right)\left(3.88 \mathrm{t} \mathrm{ha}^{-1}\right)$, but in the production environment $\mathrm{P}+$, the line selected in the $\mathrm{P}+$ selection environment was lower $\left(4.46 \mathrm{t} \mathrm{ha}^{-1}\right)$ from the $\mathrm{P}$ - selection environment $\left(4.88 \mathrm{t} \mathrm{ha}{ }^{-1}\right)$, while selection in the production environment $\mathrm{P}_{-}$, the line selected in the $\mathrm{P}+$ environment 
more higher $\left(3.96 \mathrm{t} \mathrm{ha}^{-1}\right)$ than the $\mathrm{P}$ - selection environment $\left(3.79 \mathrm{t} \mathrm{ha}^{-1}\right)($ Table 2$)$. Thus, the line selected at $\mathrm{P}$ - the condition when planted under $\mathrm{P}+$ conditions then the yield-increasing.

The increasing yield on the condition $\mathrm{P}+$ due to the maximum yield of the select lines at $\mathrm{P}+$ of $8.86 \mathrm{t} \mathrm{ha}^{-1}$ and $\mathrm{P}-8.23 \mathrm{t} \mathrm{ha}^{-1}$ more higher than the maximum yield of select lines at $\mathrm{P}+$ of $6.96 \mathrm{t} \mathrm{ha}^{-1}$ and $\mathrm{P}$ - of $7.19 \mathrm{t} \mathrm{ha}^{-1}$ if the line is growing in production environment without $\mathrm{P}$. The range of a yield shows that selected lines still have a high diversity. The maximum yield of the selected line at $\mathrm{P}+$ higher than the line selected at $\mathrm{P}$ - if planted in the production environment $\mathrm{P}+$. Similarly, if planted in the production environment $\mathrm{P}_{-}$, the maximum yield of the selected line at $\mathrm{P}$ - higher than the line selected at $\mathrm{P}+$, except Pop 1 for conditions $\mathrm{P}$-. Overall, regardless of the origins population, in the production environment $\mathrm{P}+$ highest yield of $8.86 \mathrm{t} \mathrm{ha}^{-1}$, obtained from the selected lines of $\mathrm{P}+$ and in the production environment $\mathrm{P}$ highest yield $7.19 \mathrm{t} \mathrm{ha}^{-1}$ was obtained from the selected lines in $\mathrm{P}-$.

Table 2 - The average and range yield of pedigree selection of rice lines the F6 generation in the different phosphorus condition

\begin{tabular}{llllll}
\hline \multirow{2}{*}{ Selection Environment } & & \multicolumn{4}{c}{ Production Environtment } \\
& & \multicolumn{2}{c}{$(\mathrm{P}+)$} & \multicolumn{2}{c}{$(\mathrm{P}-)$} \\
\cline { 2 - 6 }$+\mathrm{P}$ & Population & $\begin{array}{c}\text { Yield } \\
\left.(\mathrm{t} \mathrm{ha})^{-1}\right)\end{array}$ & Range & $\begin{array}{c}\text { Yield } \\
\left(\mathrm{t} \mathrm{ha}^{-1}\right)\end{array}$ & Range \\
\hline & Pop-1 & $4.63 \mathrm{a}$ & $2.21-8.86$ & $4.04 \mathrm{a}$ & $2.22-6.96$ \\
& Pop-2 & $4.28 \mathrm{~b}$ & $2.23-7.66$ & $3.87 \mathrm{a}$ & $2.15-6.68$ \\
$-\mathrm{P}$ & Rerata & $4.46 \mathrm{~b}$ & $2.56-8.86$ & $3.96 \mathrm{a}$ & $2.15-6.96$ \\
& Pop-1 & $5.89 \mathrm{a}$ & $2.12-8.23$ & $4.27 \mathrm{a}$ & $2.12-7.19$ \\
& Pop-2 & $3.87 \mathrm{~b}$ & $2.47-5.64$ & $3.31 \mathrm{a}$ & $2.05-6.19$ \\
& Rerata & $4.88 \mathrm{~b}$ & $2.12-8.23$ & $3.79 \mathrm{~b}$ & $2.05-7.19$ \\
& Total & $4.63 \mathrm{~A}$ & $2.13-8.86$ & $3.88 \mathrm{~B}$ & $2.05-7.19$ \\
\hline
\end{tabular}

${ }^{1}$ Pop-1: IR60080-23/Bernas Prima and Pop-2: Gampai/Progol

The values followed by the same letters in each column are not significantly different according to the t-test at the level of $5 \%$. Lowercase letters differentiate the population in the selection environment and between the average of the selection environment and uppercase letters differentiate between evaluation environments.

The average of the yield of the whole lines on two production environments and two selection environments presented in Table 2. The average of the yield Pop 1 population (IR6008023 / Bernas Prima) grown in P+ environments and selected in both P+ nor Penvironments has significant in higher yields than the Pop 2 (Gampai /Progol) population. Selection in the production environment P- indicates that the average population of Pop1 is higher than that of Pop 2 population although it is not statistically different between the two populations and the two selection environments (Table 2).

The selection simulation performed with $10 \%$ intensity and high yield criteria in each line group based on the population and origin environment of selection obtained 16 lines or 4 lines from each group. The average of the yield of each selected line group presented in Figure 4. The average of the selected lines on $\mathrm{P}+$ did not differ significantly with the lines selected in $\mathrm{P}$ - for Pop 1 populations in the production environment $\mathrm{P}+$, whereas for the Pop 2 population, the average of the selected lines on $\mathrm{P}+$ was significantly higher than that of the lines which selected on P-. Thus, the average of the yield of the Pop 1 population higher than the Pop 2 population. Therefore, in general regardless of population, to obtain high yield lines in the production environments $\mathrm{P}+$ can do in the selection environment $\mathrm{P}+$ nor $\mathrm{P}-$.

Selection on the conditions environment $P_{-}$, for Pop 1 populations, the average of the selected lines in $\mathrm{P}+$ did not differ significantly with the lines selected at $\mathrm{P}$-, while for Pop 2 population, the average of the selected lines at $\mathrm{P}+$ was higher than on those selected on $\mathrm{P}-$. It is generally seen that to obtain a high-yielding line in the production environment $\mathrm{P}$ - can be performed both in the $\mathrm{P}+$ and $\mathrm{P}$ - environments. The composition of selected lines for the 
environment $\mathrm{P}+8$ lines respectively from the selection environment $\mathrm{P}+$ and $\mathrm{P}-$, while the environment $P$ - respectively 7 and 9 (Table 3 ). This state that high yield lines from condition environment $\mathrm{P}+$ or $\mathrm{P}$ - can be obtained from the environment selection $\mathrm{P}+$ or $\mathrm{P}$-.
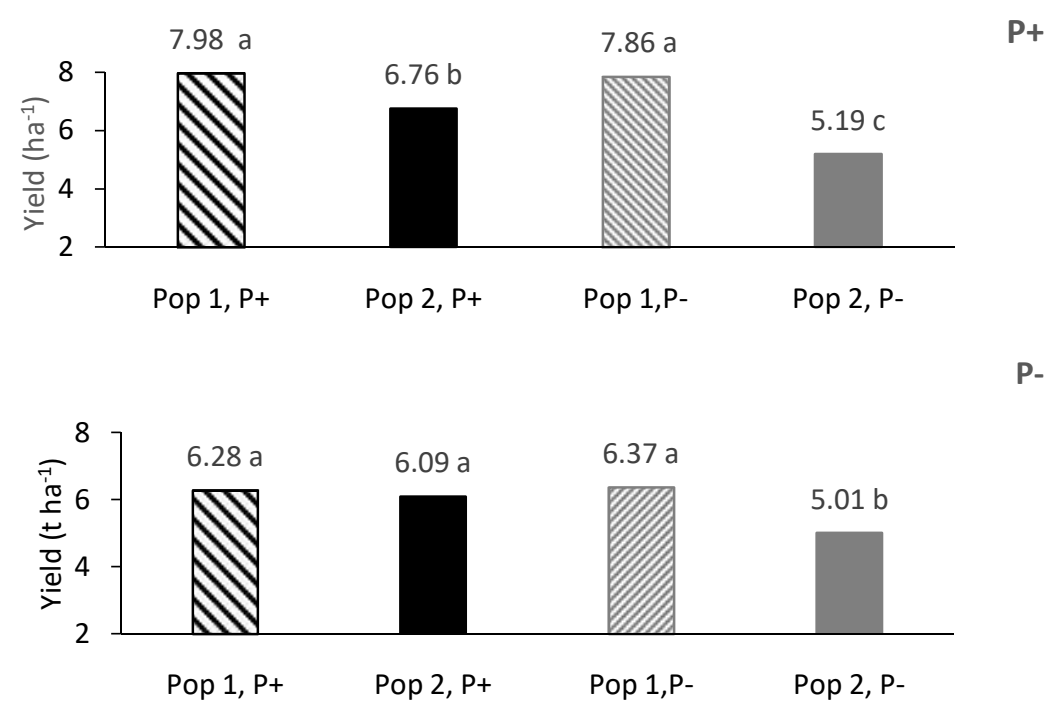

Figure 4 - Average of yield (t ha- 1 ) in the environment $P+$ and $P$ - of the $10 \%$ the best of $F 6$ generation rice lines, crossing IR6008023 / Bernas Prima (Pop 1) and Gampai / Progol (Pop 2), the results of pedigree selection in the environment P+ and P-. Values followed by the same letters are not significantly different according to a t-test at $5 \%$ level.

Based on the population of origin, the number of lines selected from Pop 1 more than Pop 2. In the environment, P+ and P- respectively are obtained 13 and 11 lines Pop 1 and then 3 and 5 line Pop 2. Showed that the most of selected line give high yield comes from Pop 1 population (IR60080-23/Bernas Prima) as many as 13 lines at the condition P+ and 11 lines at condition P- (Table 3 ).

Table 3 - The composition of selected lines with high yield for environment $\mathrm{P}+$ and $\mathrm{P}$ - according to the origin

\begin{tabular}{cccccc}
\hline \multirow{2}{*}{ Environment } & \multirow{2}{*}{ Number of selected lines } & \multicolumn{3}{c}{ Origin } \\
\cline { 3 - 5 } & & \multicolumn{3}{c}{ Environment of Selection } & \multicolumn{2}{c}{ Population } \\
\cline { 3 - 5 } & 16 & $8+$ & 8 & Pop 1 & Pop 2 \\
\hline P+ & 16 & 7 & 9 & 13 & 3 \\
P- & & 8 & 11 & 5 \\
\hline
\end{tabular}

Population Pop 1 give high yield because of the parent use in this experiment is Bernas Prima as a rice hybrid. Rice of hybrid selected for high yield. One of the mechanism hybrids is collecting dominant gene which impacts positively to yield (Satoto and Suprihatno 2008). IR60080-23 has the superiority of tolerance to aluminum toxicity. Thus, that crosses combine high yield and adaptive to low $\mathrm{P}$ conditions. Meanwhile, Pop 2 population is the result of the crossing between local varieties of Gampai with Progol. The superiority from Gampai is tolerance to blast disease with a board spectrum, whereas Progol is tolerance to aluminum toxicity. Therefore, this cross combine of possibility more adaptive into condition low Phosphorus, but yield potential does n't too high. this situation seen from 16 lines select only 3 line in the condition P+ and 5 line in the condition P- (Table 4).

Simulation of selection with the intensity of $10 \%$ and high yield for the whole lines without regard selection environment and the origin of the population obtain respectively 16 lines in environment $\mathrm{P}+$ and $\mathrm{P}$-. Selected lines arranged from high until low yield performed on Table 4. In the P + environment, the lines which selected showed an average yield of 7.35 $t$ ha-1 with a range of $6.53-8.86 \mathrm{t}$ ha-1, while in the environment $P-6,13 \mathrm{t}$ ha-1 with a range $5,14-7,19 \mathrm{t}$ ha-1. All lines selected for two different selection its higher yield and 
significantly different than the best comparison varieties. Shows that the pedigree selection method can produce adaptive and high-yielding lines in the condition of the $\mathrm{P}+$ and $\mathrm{P}$ environments (Table 4).

Table 4 - The average of the yield $10 \%$ of the best F6 generation rice lines in the optimum $P$ production environment and suboptimum $\mathrm{P}$ obtained from the pedigree method selection

\begin{tabular}{|c|c|c|c|c|c|}
\hline \multirow{2}{*}{$\begin{array}{l}\text { Environment } \\
\text { production }\end{array}$} & \multirow[b]{2}{*}{ Ranks } & \multirow[b]{2}{*}{ Lines } & \multirow[b]{2}{*}{ Yield $\left(\mathrm{t} \mathrm{ha} \mathrm{a}^{-1}\right)$} & \multicolumn{2}{|c|}{ Origin } \\
\hline & & & & Population & $\begin{array}{l}\text { Selection } \\
\text { environment }\end{array}$ \\
\hline \multirow[t]{18}{*}{$\overline{P+}$} & 1 & B14252C-MR-113P-S-5-3-2 & $8.86^{*}$ & Pop 1 & $\mathrm{P}+$ \\
\hline & 2 & B14252C-MR-101P-S-2-5-5 & $8.49^{*}$ & Pop 1 & $\mathrm{P}+$ \\
\hline & 3 & B14252C-MR-4P-S-1-1-5 & $8.23^{*}$ & Pop 1 & P- \\
\hline & 4 & B14252C-MR-96P-S-5-4-2 & $8.07^{*}$ & Pop 1 & P- \\
\hline & 5 & B14252C-MR-220P-S-5-1-1 & $7.91^{*}$ & Pop 1 & P- \\
\hline & 6 & B14251C-MR-21P-O-3-5-4 & $7.66^{*}$ & Pop 2 & $\mathrm{P}+$ \\
\hline & 7 & B14252C-MR-132P-O-5-1-3 & $7.31^{*}$ & Pop 1 & $\mathrm{P}+$ \\
\hline & 8 & B14252C-MR-95P-O-2-3-2 & $7.26^{*}$ & Pop 1 & $\mathrm{P}+$ \\
\hline & 9 & B14252C-MR-149P-S-2-3-1 & $7.24^{*}$ & Pop 1 & P- \\
\hline & 10 & B14252C-MR-251P-S-1-4-2 & $6.93^{*}$ & Pop 1 & P- \\
\hline & 11 & B14252C-MR-241P-S-1-2-3 & $6.76^{*}$ & Pop 1 & P- \\
\hline & 12 & B14252C-MR-3P-O-4-1-5 & $6.74^{*}$ & Pop 1 & $\mathrm{P}+$ \\
\hline & 13 & B14251C-MR-259P-S-1-5-1 & $6.59^{*}$ & Pop 2 & $\mathrm{P}+$ \\
\hline & 14 & B14252C-MR-68P-S-5-4-3 & $6.55^{*}$ & Pop 1 & $\mathrm{P}-$ \\
\hline & 15 & B14252C-MR-136P-S-8-2-3 & $6.55^{*}$ & Pop 1 & P- \\
\hline & 16 & B14251C-MR-174P-O-1-4-5 & $6.53^{*}$ & Pop 2 & $\mathrm{P}+$ \\
\hline & & Rata-rata & $7.35 \mathrm{a}$ & & \\
\hline & & Inpari 13 & 4.51 & & \\
\hline \multirow[t]{18}{*}{ P- } & 1 & B14252C-MR-68P-S-5-4-3 & $7.19^{*}$ & Pop 1 & P- \\
\hline & 2 & B14252C-MR-152P-S-2-2-5 & $6.96^{*}$ & Pop 1 & $\mathrm{P}+$ \\
\hline & 3 & B14251C-MR-259P-S-1-5-1 & $6.68^{*}$ & Pop 2 & $\mathrm{P}+$ \\
\hline & 4 & B14251C-MR-166P-S-1-3-2 & $6.56^{*}$ & Pop 2 & $\mathrm{P}+$ \\
\hline & 5 & B14252C-MR-113P-S-5-3-2 & $6.41^{*}$ & Pop 1 & $\mathrm{P}+$ \\
\hline & 6 & B14251C-MR-281P-S-4-5-1 & $6.19^{*}$ & Pop 2 & P- \\
\hline & 7 & B14252C-MR-220P-S-5-5-4 & $6.15^{*}$ & Pop 1 & P- \\
\hline & 8 & B14252C-MR-271P-S-5-1-4 & $6.10^{*}$ & Pop 1 & P- \\
\hline & 9 & B14252C-MR-3P-O-4-1-5 & $6.09^{*}$ & Pop 1 & $\mathrm{P}+$ \\
\hline & 10 & B14252C-MR-251P-S-1-4-2 & $6.04^{*}$ & Pop 1 & P- \\
\hline & 11 & B14252C-MR-220P-S-5-1-1 & $5.76^{*}$ & Pop 1 & P- \\
\hline & 12 & B14252C-MR-136P-S-8-2-3 & $5.74^{*}$ & Pop 1 & P- \\
\hline & 13 & B14252C-MR-101P-S-2-5-5 & 5.66 & Pop 1 & $\mathrm{P}+$ \\
\hline & 14 & B14251C-MR-128P-S-8-1-1 & 5.66 & Pop 2 & $\mathrm{P}+$ \\
\hline & 15 & B14252C-MR-95P-O-2-3-2 & 5.48 & Pop 1 & $\mathrm{P}+$ \\
\hline & 16 & B14251C-MR-98P-O-4-5-2 & 5.44 & Pop 2 & $\mathrm{P+}$ \\
\hline & & Rata-rata & $6.13 \mathrm{~b}$ & & \\
\hline & & Gampai & 4.41 & & \\
\hline
\end{tabular}

Values followed by the same letter show not significantly different according to the t-test at the level of $5 \%$.

${ }^{*}$ ) markedly higher than the best comparison varieties Inpari 13 and Gampai based on the LSI test at the level of $5 \%$.

The sequence of lines in Table 4 shows that for the environment the $\mathrm{P}+$ and $\mathrm{P}-$, it is not influenced by the selection environment, but the origin of the population is very influential, especially in the $P+$ environment. The situation can see from the 5 top sequence lines in the $\mathrm{P}+$ environment derived from the Pop 1 population.

The lines evaluated and obtained through the pedigree selection method were carried out under $\mathrm{P}+$ and $\mathrm{P}$ - conditions, followed by individual selection in the F5 generation. The individual selection has done on criteria related to yield, namely panicle size, number of tillers, and yield per hill. The lines selected in the condition $\mathrm{P}$ - has high yields and tolerance to low $P$ while from $P+$ only high yield and it's not tolerance for P-. From $10 \%$ selected lines almost the same between condition $\mathrm{P}_{+}$and $\mathrm{P}_{-}$. Of the 16 selected lines for $\mathrm{P}+$ and $\mathrm{P}$ obtained nine lines performance good in both of environments. Of the six high yield lines for condition $\mathrm{P}+$ obtained three lines selected equal on the environment $\mathrm{P}_{-}$, that is $\mathrm{B} 14252 \mathrm{C}$ MR-113P-S-5-3-2, B14252C-MR-101P-S-2-5-5 and B14252C-MR-220P-S-5-1-1. 
This situation shows the selection to get high yield lines can do in environment $\mathrm{P}+$ or $\mathrm{P}$ The lines with high yields on the different condition environments are present in Table 5 . Although selected for both conditions $\mathrm{P}$, the lines are in a different order or rank in $\mathrm{P}+$ and $\mathrm{P}$ (Table 5). However, there is one line that is in the same sequence for $P+$ and $P$-. This line is B14252C-MR-251P-S-1-4-2. They are in order number 10 and the yield a significantly higher than comparison the best varieties. The further emphasizes to get high yield lines on $P+$ nor $\mathrm{P}$ - the selection is conduct on condition environment $\mathrm{P}+$ or $\mathrm{P}$-.

Table 5 - Nine adaptive F6 generation rice lines at optimum $P(P+)$ and $P$ suboptimum $(P-)$ conditions

\begin{tabular}{lllllll}
\hline \multirow{2}{*}{ ES $^{1}$} & Population & Lines & \multicolumn{3}{c}{ Production Environment } \\
& & & Ranks & \multicolumn{2}{c}{$\begin{array}{c}\text { P- } \\
\text { Yield (t ha }\end{array}$} & Ranks \\
\hline P+ & Pop 1 & B14252C-MR-113P-S-5-3-2 & 1 & $8.86^{*}$ & $6.41^{*}$ & 5 \\
P+ & Pop 1 & B14252C-MR-95P-O-2-3-2 & 8 & $7.26^{*}$ & 5.48 & 15 \\
P+ & Pop 1 & B14252C-MR-101P-S-2-5-5 & 2 & $8.49^{*}$ & 5.66 & 13 \\
P+ & Pop 1 & B14252C-MR-3P-O-4-1-5 & 12 & $6.74^{*}$ & $6.09^{*}$ & 9 \\
P+ & Pop 2 & B14251C-MR-259P-S-1-5-1 & 13 & $6.59^{*}$ & $6.68^{*}$ & 3 \\
P- & Pop 1 & B14252C-MR-68P-S-5-4-3 & 14 & $6.55^{*}$ & $7.19^{*}$ & 1 \\
P- & Pop 1 & B14252C-MR-136P-S-8-2-3 & 15 & $6.55^{*}$ & $5.74^{*}$ & 12 \\
P- & Pop 1 & B14252C-MR-251P-S-1-4-2 & 10 & $6.93^{*}$ & $6.04^{*}$ & 10 \\
P- & Pop 1 & B14252C-MR-220P-S-5-1-1 & 5 & $7.91^{*}$ & $5.76^{*}$ & 11 \\
\hline
\end{tabular}

${ }^{1} E S=$ Environment Selection.

\section{CONCLUSION}

The pedigree selection method applied to the results of early generation rice crosses up to F4 followed by line selection, can produce adaptive and high yielding lines in the $\mathrm{P}+$ and P-. The combination of IR6008023 / Bernas Prima crosses produces lines with high yield potential compared to Gampai / Progol. From this study obtained 12 lines for P- and 16 lines for $\mathrm{P}+$ with higher yields than the best comparison varieties. Five lines with the highest yield for P- are B14252C-MR-68P-S-5-4-3, B14252C-MR-152P-S-2-2-5, B14251C-MR-259P-S-15-1, B14251C-MR-166P-S-1-3-2, and B14252C-MR-113P-S-5-3-2, while for $\mathrm{P}+$ are B14252C-MR-68P-S-5-4-3, B14252C-MR -152P-S-2-2-5, B14251C-MR-259P-S-1-5-1, B14251C-MR-166P-S-1-3-2 and B14252C-MR-113P-S-5-3-2.

\section{ACKNOWLEDGMENTS}

Thank you to the Research and Development Agency and the Indonesian Center for Rice Research, Ministry of Agriculture, which has supporting conducting research and scholarship to the writer since studies in Bogor University Indonesia, and colleague technician, the researcher staff in experimental Farm Muara, Bogor. Not forgetting the author's thanks to the Head and staff of the Technical Implementation Unit (UPT) Leuwiliang, Bogor, so the research went smoothly.

\section{REFERENCES}

1. Acquaah G. Principle of Plant Genetics and Breeding. 2007. Australia (AU): Blackwell Publishing. 584 pages

2. Balemi T, Negisho, K. 2012. Management of soil phosphorus and plant adaptation mechanisms to phosphorus stress for sustainable crop production: a review. Journal of Soil Science and Plant Nutrition. 12(123):547-561.

3. Chin JH, Gamuyao R, Dalid C, Bustaman M, Prasetiyono J, Moeljopawiro S, Wissuwa M, Heuer S. 2011. Developing rice with high yield under phosphorus deficiency: Pup1 sequence to application. Plant Physiology. 156: 1202-1216. doi: 10.1104/pp.111.175471 
4. Gamuyao R, Chin JH, Tanaka JP, Pesaresi P, Catausan S, Dalid C, Slamet LI, Mendoza EMT, Wissuwa M, Heuer S. 2012. The protein kinase Pstol1 from traditional rice confers adaptive of phosphorus deficiency. Nature. 488:535-539. doi: 10.1038/nature11346

5. Hairmansis, A., B. Kustianto, Supartopo, and Suwarno. 2010. Correlation

6. analysis of Agronomic characters and grain yield of rice for tidal swamp

7. areas.Indonesian Journal of Agricultural Science. 11(1):11-15.

8. Lubis, E., R. Hermanasari, Sunaryo, A. Santika, and E. Suparman. Toleransi galur padi gogo terhadap cekaman biotik. Dalam Prosiding Apresiasi Hasil Penelitian Padi. Buku II. Sukamandi. 2007. 725:739

9. Mulyani A, Ritiung S, Las I. 2011. Potensi and ketersediaan sumber daya lahan untuk mendukung ketahanan pangan. J Litbang Pertanian. 30(2):73-80.

10. Parentoni SN. Mendes FF. Guimaraes LJM. 2012. Breeding for Phosphorus Use Efficiency. Dalam Neto RF and Borem A (eds). Plant Breeding for Abiotic Stress Adaptive. Springer-Verlag Berlin Heidelberg.

11. Pariasca JT, Kouji Satoh, Terry Rose, Ramil Mauleon, Matthias Wissuwa. 2009. Stress response versus stress tolerance A transcriptome analysis of two rice lines contrasting in tolerance to phophorus deficiency. Rice. 2:167-185.

12. Prasetiyono J. 2012. Evaluasi beberapa galurP-up1 tanaman padi (Oryza sativa L.) pada larutan hara and lapangan. J. Agron. Indonesia. 40(2):83-90.

13. Prasetyo, B.H. and D.A. Suriadikarta. 2006. Karakteristik, potensi, and teknologi

14. pengelolaan tanah Ultisol untuk pengembangan pertanian lahan kering di Indonesia. J.Litbang Pertanian 25(2):40-46.

15. Peterson, R.G. 1994. Agricultural Field Experiments Design and Analysis. New York (US): Marcel Dekker, Inc.

16. Richardson AE, Hocking PJ, Simpson RJ, George TS. 2009. Plant mechanisms to optimise access to soil phosphorus. Crop Pasture Sci. 60:124-143. Doi:10.1071/CPO71251836-0947//09/020124

17. Suharta N. 2010. Karakteristik and permasalahan tanah marginal di Kalimantan. J Litbang Pertanian. 29(4):139-146.

18. Wang X, Shen J, Liao H. 2010. Acquisition or utilization. which is more critical for enhancing phosphorus efficiency in modern crops? Plant Science. 179:302-306.

19. Wissuwa M, M. Mazzola, and C. Picard. 2009. Novel approaches in plant breeding for rhizosphere-related traits. Plant and Soil. 321(1):409-430.

20. Vance CP, Uhde-Stone C, Allan DL. 2003. Tansley review phosphorus acquisition and use: critical adaptations by plants for securing a non renewable resource. New Phytol. 157:423-447. 